Vaneasa Online Journal

4.2 | 2016

Imagination/Ineffability

\title{
A Remarkable Convergence
}

\section{Paul Stoller}

\section{(2) OpenEdition \\ Journals}

Electronic version

URL: http://journals.openedition.org/anthrovision/2332

DOI: 10.4000/anthrovision.2332

ISSN: 2198-6754

\section{Publisher}

VANEASA - Visual Anthropology Network of European Association of Social Anthropologists

\section{Electronic reference}

Paul Stoller, «A Remarkable Convergence », Anthrovision [Online], 4.2 | 2016, Online since 31

December 2016, connection on 04 May 2019. URL : http://journals.openedition.org/anthrovision/2332 ; DOI : 10.4000/anthrovision.2332

This text was automatically generated on 4 May 2019.

(c) Anthrovision 


\title{
A Remarkable Convergence ${ }^{1}$
}

\author{
Paul Stoller
}

1 In my years as an anthropologist I have long held the assumption, which is perhaps a tad naïve, that anthropologists could transcend the cultural gulf of difference that separates them from their others. I assumed that if you learned to speak the other's language fluently, your linguistic competence would be a strong indication of deep cultural respect, which could, in time, foster profound understanding and friendship between peoples defined by difference. That assumption compelled me to deepen my knowledge of the Songhay language. I studied proverbs and learned to talk about little discussed cultural matters-the names of plants, the use of spices in Songhay cooking, expressions associated with farming and healing. The use of these specialized elements of the Songhay language usually impressed my interlocutors. They praised my command of the Songhay language. In markets the anomaly of a white man speaking "old" Songhay attracted crowds of on-lookers.

"Where did you learn Songhay? a few people would ask.

"You speak Songhay better than me," some would say with not a small degree of exaggeration.

When I "did" the famous market of Ayorou on the banks of the Niger River not far from the border between Niger and Mali, crowds of young people would come to listen me bargain for a beautiful hand-woven Songhay blanket. One day a man from Mehanna, the Songhay town where I conducted my early fieldwork, joined the crowd of Ayorou onlookers.

5 "Who is this white man who speaks Songhay? someone asked.

6 "He's our white man," the Mehanna man chimed in.

7 The long-term relationships I established in the field also reinforced this assumption. I studied with my teacher Adamu Jenitongo for more than 17 years. During that time I felt that we had developed an intimate bond-the loving ties of a father to his son. We had, or so I thought, bridged the wide cultural gulf that had separated us.

In 1988, I mourned his death, which not only brought to an end the life of a wise man, but also changed my life as a field anthropologist. After his death, how could I go on with my 
work in Niger? Who could replace my mentor? I tried to do new fieldwork but the situation in Tillaberi, the town where he had lived and I had done fieldwork, quickly deteriorated.

Despite my disappointments in Niger, I carried the same assumption with me to New York City the site of my fieldwork on West African immigrants. Although I never developed a relationship there that resembled the deep bonds I had shared with Adamu Jenitongo, I still felt that my linguistic and cultural knowledge of things Songhay might enable me to establish friendships that bridged the gulf of social and cultural difference. I liked the fact that in New York City my Nigerien friends called me "brother," and said that I spoke Songhay like a native. I especially liked it when they bragged about me to their customers.

"He's lived in my village."

"He knows our history."

"He's a boro hano (a pure/good person)

When my friends said: "He's really a Songhay."

seen in the river for years, it can never become a crocodile." I'd follow that proverb, which would invariably provoke much appreciative laughter, with affirmations that I was and would always be an American.

fis would disagree, which would quietly reaffirm the premise that I was somehow different from other white people. One day in 2004 a conversation weakened the foundation of that assumption. I phoned Issifi Mayaki who had been one of my longstanding Nigerien friends in New York. Issifi and I shared a passion for political discussion, but also had enjoyed long and intense debates about religion and culture. We often talked about racism and the general American ignorance about Africa and Africans. He liked to call me his "brother."

After several rings, Isiifi's real brother, whom I hadn't met, picked up the phone.

17 I introduced myself. In the background I heard Issifi ask who was on the phone.

His brother said, "Paul."

"Oh, that's the white man," Issifi said, not knowing he had been overheard. Moments later, he picked up the phone and said: "Paul! How are you, my brother?"

21 For me that incident underscored powerfully that the relationship of non-native anthropologists to their others is vexingly complex. In a short essay in 2005 I wrote about my immediate reaction to the incident, coming to the conclusion that ...my particular capacities as a fieldworker or as a human being could not alter an always already set of racially-defined sociological boundaries-of pre-colonial and colonial culture-established and solidified years before I had set foot in Niger...How disappointing it is for ethnographers to admit, and in my case it was a grudging admission, that the relationships that they develop in the field, while close, are, in fact, not usually as special as they might think... ${ }^{2}$

One phone conversation did not dispel the feeling that my experiences in the Songhay worlds of sorcery and trade nonetheless had put me in a different category, a category in which a set of common understandings gave me insights into the social realities of my friends. And yet, the applicability of the aforementioned proverb never seemed stronger: 

multilingual as well. Accordingly, many of the market-savvy residents in Belayara speak not only Songhay, but Hausa, the major trade language in West Africa, and Tamasheq, the language of the Tuareg nomads. Put another way the size and reputation of the market makes the small town of Belayara, which is 65 kilometers northeast of Niamey, Niger's capital, a cosmopolitan space. Many of its inhabitants have traveled far and wide following long established as well as more recent trading routes. deep impact on your worldview. From an early age Yaya and his brothers, Abdou, and Daouda learned that the trading life was an honorable one, a life that could bring a person both money and social prestige. They learned that truly prosperous merchants not only enjoyed material prosperity, but possessed "wealth in people," a person with a wide network of people whom you could trust ${ }^{3}$.

king with senior traders, the young Yaya learned that Islam is central to trading practices. The key to successful trading, according to the hadith of the Prophet Muhammad, devolved from relations based upon mutual trust. If a trader extended credit to trading partner, he or she would expect that the credit to be repaid. If a trader purchased goods from a partner, he or she would expect that partner to ship those goods. 
A blanket trader in the Belayara Market, 2009

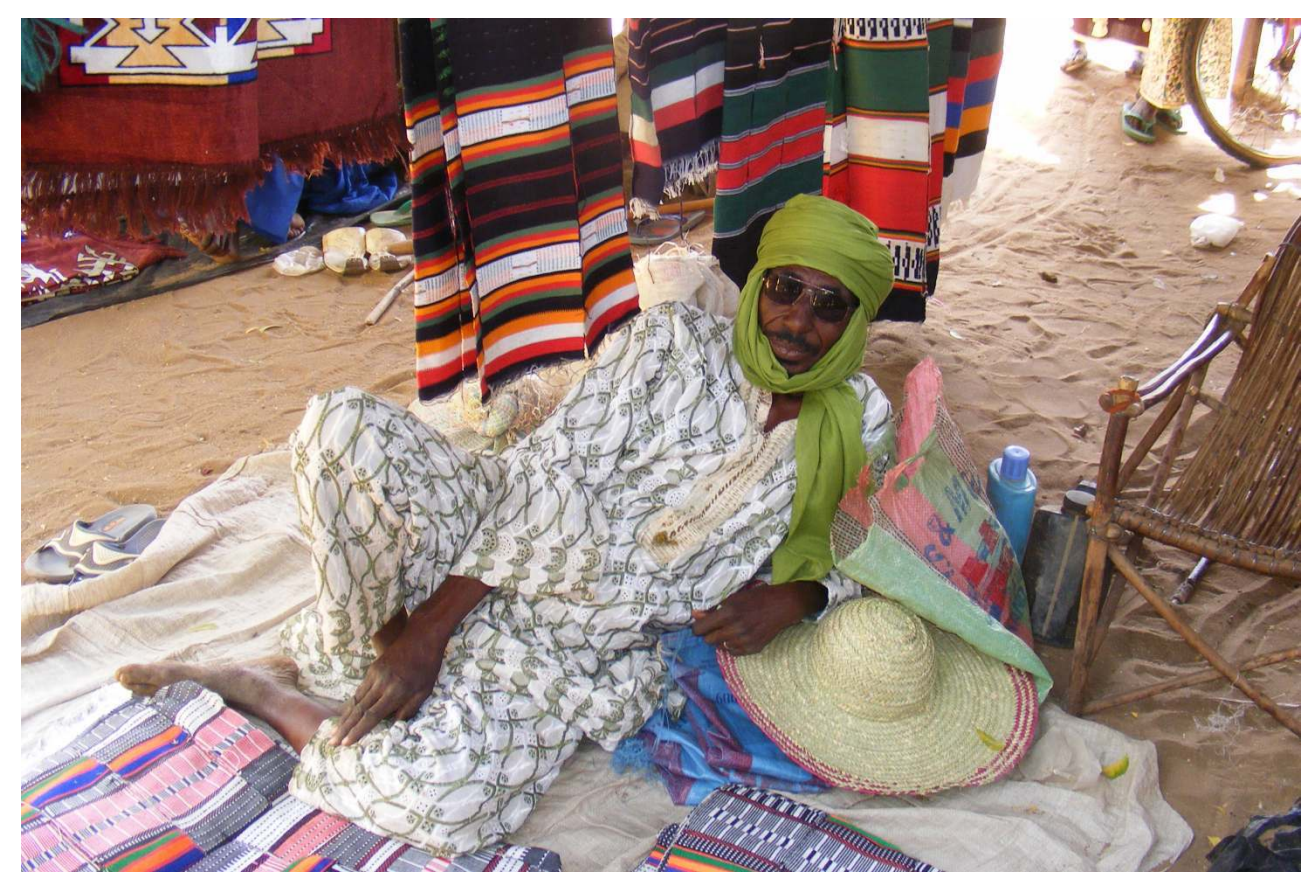

PHOTO BY PAUL STOLLER

And so growing up in Belayara exposed Yaya and his brothers to the West African culture of trade, the lure of the good sale, the adventure of travel but also to the considerable comforts of home. When traders returned to the market from long trips to Niamey, Niger's capital, to Lagos, Nigeria, or Lome, Togo and most especially the thriving metropolis of Abidjan, Cote d'Ivoire, they would recount their adventures in distant worlds of wonder--the food of youthful imagination gave young men the appetite for travel. But they also stressed how good it was to return to the familiar smells and sights of home. What could be better than to return to the warm embrace of their mothers and fathers, aunts and uncles and brothers and sisters?

Abdou, Yaya's older brother, left Belayara in the late 1950s. A fraternal relative invited him to work in Abidjan, which, at that time, was a fabled commercial city. The young Abdou sold watches and bracelets in Abidjan markets and following the instructions of his elders, saved as much money as he could. In time, he had the capital to buy and sell his own goods-soap, hard candy, chewing gum, homespun cloth, bracelets, and cheap watches. Because of his entrepreneurial talents, he gradually expanded his network of suppliers and clients. By the time he was in his early twenties Abdou had fashioned himself a place in Abidjan's economic life. He had become a trader of nyama-nyama, a little bit of everything.

Although Abdou had learned to speak, read and write French in elementary school, he saw his future along the path of commerce. Yaya, too, attended primary school and did well enough to become a student at the middle school in Fillingue, the provincial capital. There, he boarded with a family that housed and fed him-not always so well. Despite being far from kith and kin, Yaya liked studying French, math and science, and also took to the study of English, which was required in middle school. Like his father and older brother, he made sure to recite his prayers five times a day, and when the month of Ramadan occurred during the school year, he fasted from sun up to sun down. 

traders at a six-story warehouse on the west side of Manhattan just a block from the Hudson River. Abdou specialized in the masks and statues of the Baule and Guro peoples, who reside in Cote d'Ivoire. Daouda sold antique weapons from West and Central Africa. Yaya, for his part, traded very old terra cotta figures from the Bura region of Niger. He also continued to sell various versions of the Agadez Cross-all inspired by the Southern Cross constellation.

\section{One version of the Agadez Cross}

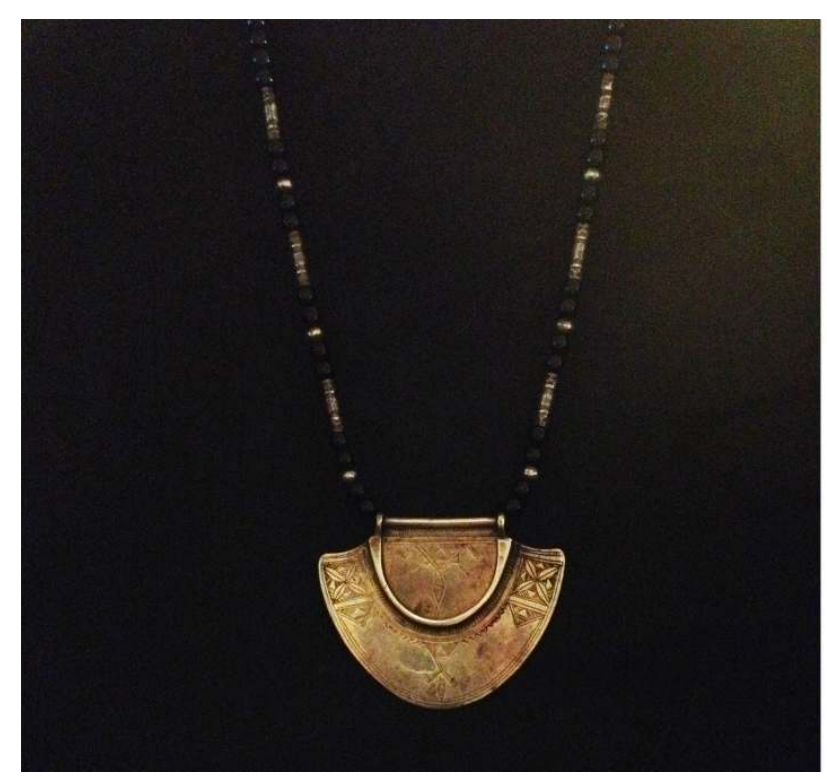

PHOTO BY PAUL STOLLER 
An Old Bura Reliquary Figure

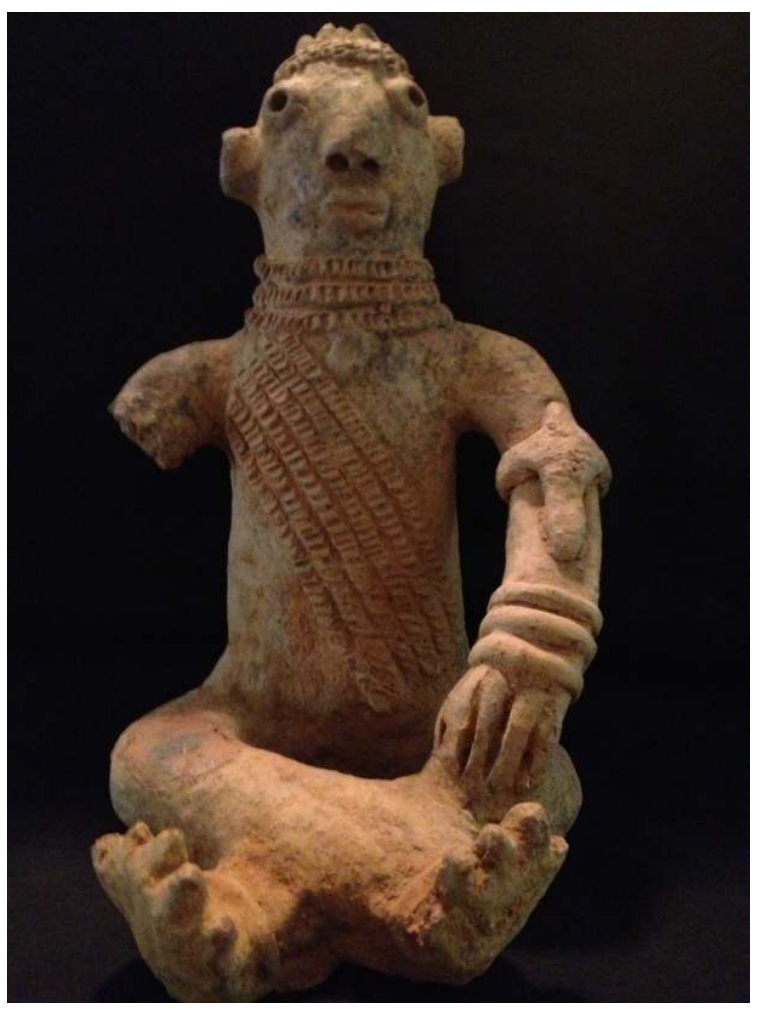

PHOTO BY PAUL STOLLER

\section{Paul Stoller's World}

My beginnings could not have been more different from those of Yaya. Unlike the young Yaya who lived in Belayara, Niger in a small mud brick house that lacked running water and interior plumbing, I spent my childhood and adolescence in a modest three-bedroom house in a middle class neighborhood of Silver Spring, Maryland, which is a close-in suburb of Washington D.C. We had a bathroom, a powder room, a basement and lots of space in a grassy backyard where I played with my childhood friends.

My parents, Sidney Stoller and Goldie Berman, came from thoroughly Jewish households. My great grandfather, Joe Stoller, was a carpenter who built and repaired houses in small villages in Belorussia. He trained his son, Mack, in the trade. But the early years of the 20 th century brought turmoil to Belorussia-especially for Jews. Seeking refuge from Cossack pogroms and from eventual conscription into the Czar's World War I Army, father and son slipped out of Belorussia and landed in Windsor, Canada. They eventually established themselves in Detroit, where, when resources permitted, they brought over other members of the family.

My grandfather, Mack Stoller, married Rose Swartz, the oldest child of the inimitable Swartz family. They had three children: Sidney, my father, Raymond and Beverly. My father was born in Detroit in 1920. A few years later the family moved to Washington DC where some of their landsmann (people from the same village) had settled. At that time Washington D.C. seemed to be a city of limitless opportunity. My grandfather left the bulk of the family, including my great-grandfather, back in Detroit, where Joe Stoller had a 
modest business. For his part, my grandfather used his meager savings to open a small grocery store in Southwest Washington D.C. The store was not a great success. Struggling in the grocery business, my grandfather's landsmann encouraged him to go into the building business. Working hard in a trade business that he had known since childhood, he made enough money to provide my father and his siblings a comfortable home and a relatively prosperous life. In 1938 my father and his brother Raymond shared a car-with a rumble seat no less!

40 My father attended law school but did not find the law to his liking. As World War II unfolded he and his brother joined the armed forces. My father was a sharp shooter and sniper in places like Guadalcanal. After the war, Raymond went to medical school and Sidney went to work for my grandfather, which marked the birth of an enterprise called Stoller and Son, Inc. Carpentry Contractors. My father and grandfather's company helped to build suburban houses in Silver Spring, Maryland. Indeed, we lived in one of the houses that my father and grandfather had built. Stoller and Son also did the carpentry work for many of the high-rise and garden apartments in the Washington DC Metropolitan area.

41 My mother came from more modest circumstances. Her Jewish parents escaped from Latvia and made their way to Montreal, Canada. Eventually they moved from Montreal to Cambridge, Massachusetts. When his business prospects turned sour there, my maternal grandfather moved the family-two boys and three girls, including, of course my mother Goldie, to Washington DC. On the streets of the Nation's capital, my grandfather, Morris, became a fruit peddler. Unfortunately, he had a taste for gambling. He worked hard work and earned money, which, he squandered on pinochle and poker. Scrambling for income, my maternal grandmother, Leah, turned her home into a boarding house. My mother, then, grew up in a relatively poor Jewish home in which scant resources were reserved for the two boys in the household who, it was hoped, would eventually end the family's economic plight. 


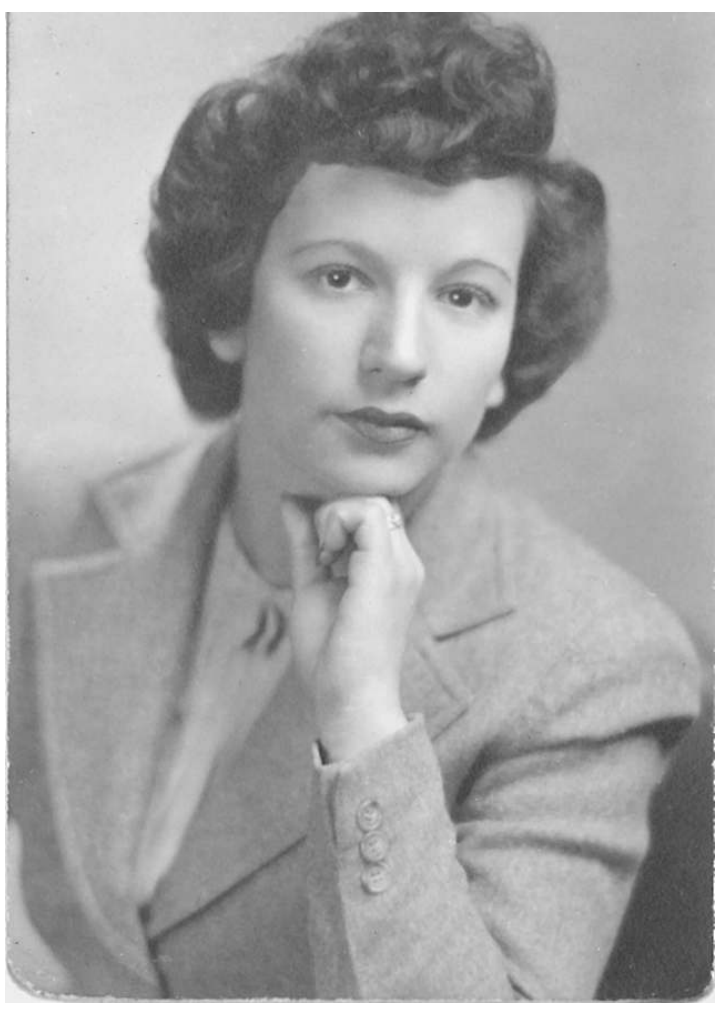

PHOTO FROM STOLLER FAMILY ARCHIVE

My parents met and fell in love during the hard times of the late 1930s. The uncertainties precipitated by the onslaught of World War II compelled them to postpone their wedding. When my father received his orders to ship out to the Pacific, they decided to get married. My mother went with him to Brownsville, Texas where he suffered through basic training. My father came back from World War II unscathed-physically at least. He never talked about what he had experienced in the sniper's perch or on the battlefield.

The business was very much a family-run enterprise. My uncle, who was, in fact, my father's sister's husband, did the books. My father's brother, Raymond, now a surgeon, provided some timely loans. There were many ups and downs in the construction business. Although Stoller and Son, Inc. was far from producing astronomical profits in the late 1950s, the business provided a good life for our family. Even so, it did not afford us a style of living that satisfied my parents.

Through talk at frequent family gatherings at the large home of my paternal grandparents, family members continuously cultivated in me a strong will to succeed, which for them meant the accumulation of wealth. They liked to tell me that you could find fortune through hard work or through marriage. My mother would always talk about young men from relative modest means who married "rich girls," and lived "happily ever after." Everyone looked to my Uncle Ray, "The Doctor," as the great success story in the family. By the time I was 10 years old, my uncle, who was my godfather, had moved back to the family digs in Detroit, and had built a private medical clinic. It was said that Uncle Ray was a millionaire. In the eyes of the family, he had become the model of and for success. 
Contrast my beginnings to those of El Hajj Yaya. When Yaya was a young boy, he learned how to sell products at the Belayara market. In addition to going to the local elementary and secondary school, he spent the early evening hours memorizing the Koran under the guidance of a local cleric. My parents sent me to Hebrew School where, during three early evening classes each week, I learned to read and write Hebrew-all in preparation for my bar mitzvah.

As I neared 13 my parents planned a large celebration to fete the emergent "manhood" of their firstborn son. They invited hundreds of people, rented the auditorium of our synagogue, bought many cases of vodka, arranged for a catered sit-down dinner, and hired the Guy Davis orchestra, featuring Jose Vargas on maracas and vocals. They also sent me off to dance school, where the inestimable Groggy Gurwitz taught me how to foxtrot, cha-cha, polka, jitterbug, and rhumba. For almost a year my mother dropped me off at Groggy's studio, where the slender, permanently tanned, peroxided and pompadoured dance instructor, who sometimes practiced law, showed us his moves. Even though I didn't particularly like my dance partners, 12-year-old Jewish girls in training for their bat-mitzvah, who, in retrospect, didn't care very much for me, Groggy's lessons gave me a ballroom dancing foundation. By February 6, 1960, I was ready to dance-and dance well-with my mother, grandmother, and aunts-all part of the grand design to use my bar-mitzvah to kvell (beam with pride) about my family's relative prosperity.

During my childhood and adolescence you also received accolades for "being smart," something highly valued in urban Jewish culture of the 1950s and 1960s. This atmosphere compelled me to work very hard in high school. I received fairly good grades and joined the debate team. If I could get accepted to an Ivy League university, I'd feel like a success. Alas, my academic record put that dream pretty much out of reach. What's more, no one in my family was a Harvard, Yale, Columbia or Penn alumnus, which meant that I had no chance of being admitted as a "legacy" student. Several select liberal arts colleges also rejected my application for admission. Finally, The University of Pittsburgh, which was a fine institution of higher learning, accepted me and off I went to college.

When my father drove me from Silver Spring to Pittsburgh the fear that pulsed through my body had little do to with leaving home for the first time. In fact, I had long looked forward to being more on my own. No, I feared the challenge of a higher education. Could I cut it? Would I prove wanting in the competition for grades at Pitt? Would they kick me out?

49 When I arrived on campus, unpacked and wandered into what was for me a brave new world, I steeled my resolve to do well. Unlike my roommate and many of the students on my dorm floor, I spent much of my spare time studying. I thought that if I spent enough time reading and taking notes, the effort might make up for my self-perceived intellectual deficiencies.

In college I majored in philosophy and political science and found passion in journalism. During my senior year, a variety of circumstances, including the War in Vietnam compelled me to join the US Peace Corps. Given my many of years of studying French, they assigned me to Niger, a dry, arid and poor West African nation. I immediately fell in love with the land and its people. I learned the Songhay language and forged friendships that endure to the present. Several months before the end of my Peace Corps tenure, I met Adamu Jenitongo, a spirit possession priest and great healer. Upon my departure he looked at me and said: "You'll be back." 
51 Five years later his prediction came to pass. Upon my return to the United States, I wanted to find a way back to Niger. First, I studied linguistics and then social anthropology. In time, I received a grant to conduct doctoral research on the religion of the Songhay people of Niger. Eventually, my path led me back to Tillaberi, the town where I had met Adamu Jenitongo. He invited me to be his apprentice. Thus began a 17year apprenticeship during which he conveyed to me much of his wisdom about plants, magic, and living in the world. When he died in 1988, I knew that my days of fieldwork in Niger would soon be over. His death precipitated much turmoil in his family and well as among rival practitioners. I did return to Niger 1990-91 to consult with my mentor's sons, but three weeks into my visit, I contracted "malaria" that wasn't malaria, a "sickness" that isn't a sickness. My Nigerien friends, who felt that I had been the target of a magical attack, feared for my life and insisted that I be evacuated. When I returned to the US, it took three months of burning special incense and ingesting special teas for me to return to "normal." Fearing another magical attack, it took 18 years for me to gather the courage to return.

And so I began fieldwork among West African traders in New York City. After several years of that fieldwork I met El Hajj Harouna at the Malcolm Shabazz Harlem, the principal site of my New York fieldwork. When El Hajj Abdou said he came from Belayara, I wondered if he were a Sugi, a sub-ethnic group of that region. "They say that the Sugi," I said, "is the cross-cousin of the sohanci (sorcerer)."

"I'm a Sugi," he admitted, smiling at me.

"That means I should begin insulting you," I stated, a smile creasing my face.

Laughter shook El Hajj Abdou's body. He slapped me playfully on the shoulder. "Okay, let's hear one."

"You mother," I began, "is so...."

He slapped his knee. "Please," he pleaded. "No more....no more."

He looked at me intently. "Why are you wasting your time here at this market? Come with me to The Warehouse. We have real merchandise there-wood (masks and statuettes) and mud (terra cotta figurines)."

"So I've heard," I said. "But my work is here."

"Come and see a real market," he insisted.

I resisted, but weakly because I wanted to see The Warehouse.

"I'm going to The Warehouse right now. Let's go."

We took the subway to Penn Station and then walked another mile or so to The Warehouse. El Hajj Abdou introduced me to his colleagues. On each subsequent visit, the art traders there welcomed me warmly. They invited me to sit, drink coffee and talk. On one such visit in February 1998, El Hajj Abdou introduced me to his brother El Hajj Yaya.

\section{Moving Toward an Existential Boundary}

Over the years, Yaya and I constructed an instrumental relationship. We exchanged services. I might steer a potential client to his stall. He would talk to me about his life and his experience as an African Art trader. Over the years he spent large chunks of time in 
Niger and Cote-d'Ivoire. When we were both in New York, we would see each other. I would also phone him from time to time.

When I began chemotherapy treatments in 2001, my world changed fundamentally. Confronted with mortality, I tried to live each and every day as fully as possible. What's more, my orientation to anthropology shifted. I wanted to concentrate more on the use narrative link anthropological insight with a larger audience of readers.

When El Hajj Yaya told me he was undergoing treatment for colorectal cancer in 2007, I was at first surprised that the nature of our relationship hadn't changed. Given my personal experience in the world of cancer I knew first hand that fellow patients often experienced a silent bond. On further reflection, I understood that the effects-both physical and psychological--of ongoing cancer treatment probably compelled him to isolate himself. I strongly believe that no matter the extent of your network of social support-and in my case the network was substantial and strong--cancer patients ultimately confront their disease alone. No one can feel your physical or existential pain. Sometimes it is simply better to retreat into the solace of solitude. And yet such solitude creates its own version of emotional pain. You want the love and support of family, but such love and support can often be unbearable. I sent him information on clinical trails, and phoned him regularly. He thanked me for sending him information, but rarely answered his phone or responded to my messages. Such are the conundrums of the cancer experience.

\section{El Hajj Yaya Harouna at the Malcolm Shabazz Harlem Market in 2009}

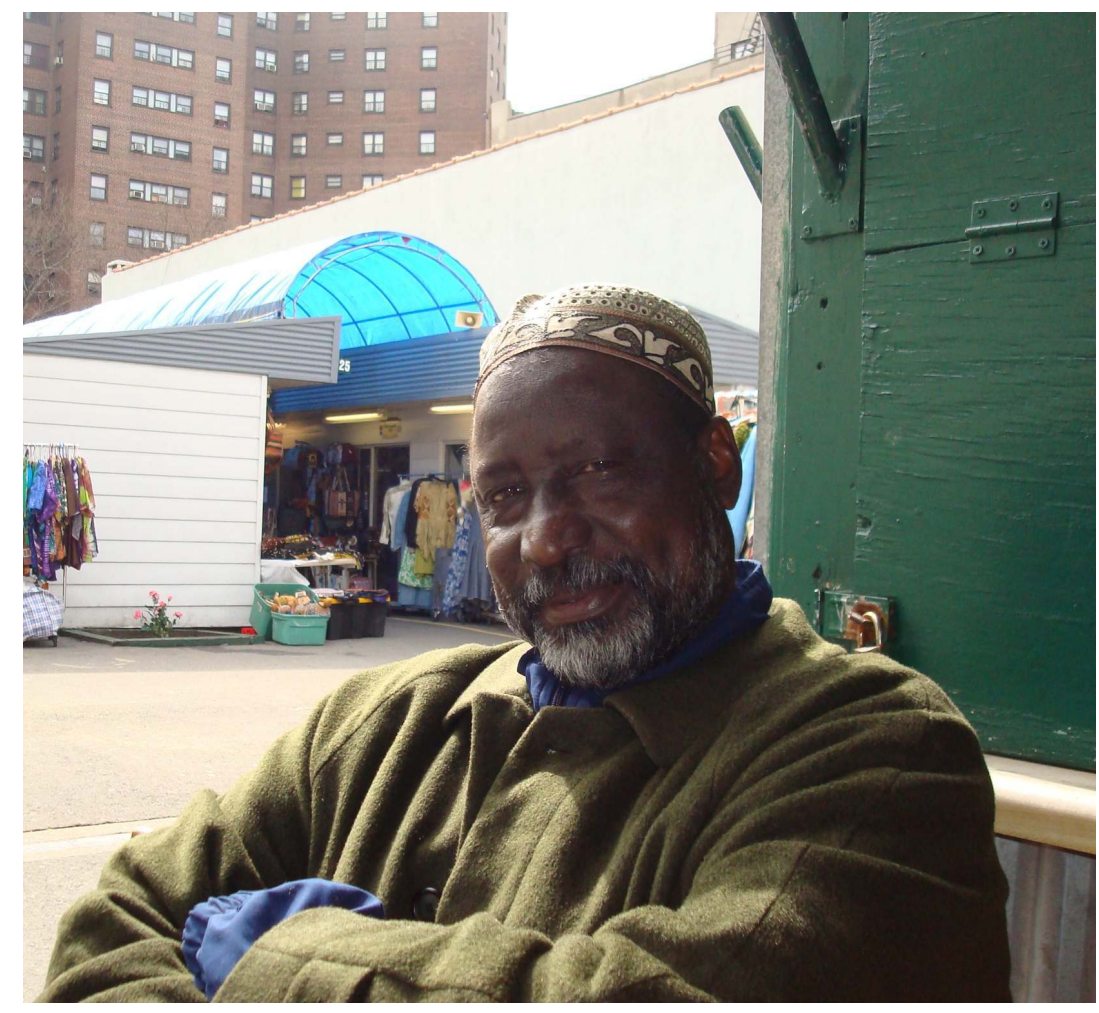

PHOTO BY PAUL STOLLER

In October 2010 I once again visited my West African friends at the Malcolm Shabazz Harlem market in New York City. Because he spent so much time alone in his apartment, I 
didn't expect to see El Hajj Yaya that day. And yet, there he was sitting on a metal chair in front of Boube Mounkaila's "leather" handbag shop.

He looked tired. He mentioned that the chemotherapy drugs had reduced the size of his tumor and that his physicians had been cautiously optimistic about his prognosis. After almost three years of on-again-off-again chemotherapy, they wanted El Hajj Yaya to continue treatment to "manage" the cancer. That day we spoke vigorously about politics in the US and Niger as well as about the twists and turns of the global economy. As always, I found El Hajj Yaya an admirable man. In the face of what seemed like terminal cancer, I admired his dignity and stoic persistence.

When the other traders in our discussion group moved away to tend to their shops, El Hajj Yaya beckoned me closer. He looked deeply into my eyes and touched my hand.

"Paul," he said solemnly, "I'm going home."

Given our recent history, this intimate statement provoked a surprise that quickly dissipated into a profound silence of mutual recognition. Like two cats perched on a wall, we sat motionlessly and let the statement sink in. He nodded his head and we sat for a few moments holding hands, a sign of deep friendship in West Africa. People strolled by. The din of conversations hung in the background. The sweet smell of Bint al Sudan perfume filled the air.

That moment was just a spark of time, a perfect instant of profound mutual comprehension and experiential convergence. For just that moment, I knew what he knew and he knew what I knew. We had crossed a distant existential boundary and entered a new space of awareness. It was what Martin Buber had brilliantly called an IThou moment of deep dialogue. ${ }^{4}$

We savored the moment. We knew it would be the last time we would see one another. In that moment of resignation, I felt a profound sadness. I don't know if El Hajj Yaya felt the same sadness and resignation.

He stood up and walked toward the market exit. A few paces from me, he turned around. "I leave in two weeks," he said in an even tone. He walked away--back to a life lived with pride and dignity.

So Yaya returned to Niger. I departed for my home in Wilmington, Delaware. He went back to his family and local businesses. I soon found myself once again among family, friends and colleagues.

Boube filled me in on what happened to El Hajj Yaya after his return to Niger. In the absence of chemotherapy treatments, cancer quickly took hold of his body. He found it difficult to eat. He found it increasingly painful to walk. A month after his arrival he took to his bed. Friends and relatives came to the family compound to pay their respects. They talked about wonderful things-travel, El Hajj Yaya's life in Abidjan and New York, his considerable success in the world of trade. In this way, people bestowed upon him the cultural honor that befits a traveler, a restless taker of risks.

77 He died on January 1, 2011.

At our last meeting El Hajj Yaya and I experienced a rare point of existential convergence, a perfect storm of mutual comprehension. Like all peak experiences in life, this one lasted only a few moments, which, for me least, have been unforgettable. Those moments changed me. They reaffirmed in me the belief that human beings from different 
backgrounds can overcome substantial difference and establish deep bonds of mutual comprehension.

Those last instants with El Hajj Yaya also gave me the imaginative courage to understand more fully what Adamu Jenitongo had taught me a long time go: "illness is a great teacher." For a long period of time, I thought that his statement referred to how sorcerers move forward on their path. It is through illness--sometimes natural, sometimes brought on through sorcerous acts--that the apprentice moves forward on her or his path of power. If you respond to illness with respect and dignity, you are ready to learn about more powerful rites and more profound truths. If you are not up to the challenge that illness presents, your journey ends at the fork in the road where your teacher guides you to another path. After the last meeting with El Hajj Yaya, I knew that illness was not only a great teacher, but also a great leveler. When I sat in treatment rooms with fellow cancer patients, I realized that illness could wash away social differences. If you are a cancer patient hooked up to an IV, it makes no difference if you are a professor or a sanitation worker. From the patient's perspective, cancer does not draw boundaries of social class. In the treatment room cancer obliterates class distinctions, for everyone there is in the same situation--experiencing an unsentimental face-to-face confrontation with mortality. What I hadn't realized, though, is that the experience of serious illness also makes it possible for two people, defined by social, cultural, linguistic and historical difference, to transcend their deep disparities, if only for a few intense moments, to experience a profound existential convergence. That convergence may have brought some existential closure to both of our lives. It may have given El Hajj Yaya a measure of comfort on his journey to a dignified death. It gave me a sharpened appreciation of the vicissitudes of life on a path toward an uncertain future. ${ }^{5}$

\section{BIBLIOGRAPHY}

Babou, Cheik Anta. 2007. Fighting the Greater Jihad: Amadu Bamba and the Founding of the Muridiyya of Senegal, 1853-1913 (New African Histories). Athens, Ohio: Ohio University Press.

Buber, Martin. 2000. I and Thou. New York: Scribners.

Ebin, Victoria. 1990. Commercants et missionaries: Une confrerie musulmane senegalaise a New York. Hommes et Migrations 1132:25-31.

Mennan, M.A. 1986. Islamic Economics: Theory and Practice. Boulder, Colo.: Westview Press.

Stoller, Paul. 2002. Money Has No Smell: The Africanization of New York City. Chicago: The University of Chicago Press.

Stoller, Paul. 2005. The Presence of the Ethnographic Present. Qualitative Sociology 28.2: 197-99.

Stoller, Paul. 2014. Yaya's Story: The Quest for Well-Being in the World. Chicago: The University of Chicago Press. 


\section{NOTES}

1. This text is adapted from my recently published book, Yaya's Story: The Quest for Well-Being in the World, The University of Chicago Press, 2014.

2. Paul Stoller 2005: 197-98.

3. For studies of Muslim conceptions of trade see Ebin 1990; Babou 2007; Mennan 1986; Stoller 2002.

4. See Martin Buber 2000.

5. See Paul Stoller 2004.

\section{ABSTRACTS}

This essay is about an ethnographic epiphany. It is a story of two men, who, separated by ethnicity, language, culture, profession, and personal circumstance, bridged their considerable differences to reach a remarkable point of existential convergence, a deep dialogue that brought on a moving moment of profound mutual understanding. Our stories recount adventures experienced along two distinct life paths. El Hajj Yaya's path followed the twists and turns of contemporary commerce. My path followed the sinuous trails of anthropology. In time our winding paths finally crossed in New York City, where we met and built a friendship. Our mutual experience of cancer gradually transcended the profound differences that separated us. Through the telling of these stories, I attempt to reflect on themes-love and hate, health and illness, courage and fear, fidelity and betrayal-that form the foundation of the anthropological enterprise and define human condition, [ethnography, representation, epistemology]

Cet essai est une révélation ethnographique. C'est l'histoire de deux hommes, séparés par leur identité ethnique, leur langue, leur culture, leur profession et leur contexte de vie personnelle, qui ont réussi à combler ces différences considérables pour parvenir à une exceptionnelle rencontre existentielle, à un dialogue fécond qui nous donne accès à un moment émouvant de compréhension mutuelle. Nos histoires racontent des aventures vécues le long de deux chemins de vie distincts.

El Hajj Yaya's suit les aléas des tours et détours propres au commerce actuel. Mon parcours personnel suit celui des pistes sinueuses de l'anthropologie. Avec le temps, nos parcours se sont croisés à New York où nous nous sommes rencontrés et où nous sommes devenus amis. Notre expérience mutuelle du cancer nous a permis progressivement de dépasser les profondes différences qui nous séparaient. En racontant ces histoires, j'essaye de réfléchir aux thèmes de la haine-de la vie, de la santé et de la maladie, du courage et de la peur, de la fidélité et de la trahison, qui forment les fondements mêmes de l'entreprise anthropologique et définit la condition humaine.

Este ensayo trata de una epifanía etnográfica. Es la historia de dos hombres que, separados por la etnicidad, el idioma, la cultura, la profesión y las circunstancias personales, superaron sus considerables diferencias para alcanzar un punto remarcable de convergencia existencial, un diálogo profundo que conllevó un momento emotivo de profunda comprensión mutua . Nuestras 
historias cuentan aventuras experimentadas a lo largo de dos caminos de vida distintos. El camino de El Hajj Yaya siguió los giros del comercio contemporáneo. Mi camino siguió los sinuosos senderos de la antropología. Con el tiempo nuestros sinuosos caminos finalmente se cruzaron en Nueva York, donde nos conocimos y construimos una amistad. Nuestra experiencia mutua del cáncer transcendió gradualmente las profundas diferencias que nos separaban. A través del relato de estas historias, intento reflexionar sobre temas -amor y odio, salud y enfermedad, coraje y temor, fidelidad y traición- que forman el fundamento del proyecto antropológico y definen la condición humana [etnografía, representación, epistemología]

INDEX

Mots-clés: ethnographie, représentation, épistémologie, bien-être

Keywords: ethnography, representation, epistemology, well-being

Palabras claves: etnografía, representación, epistemología, bienestar

\section{AUTHOR}

PAUL STOLLER

West Chester University

pstoller@wcupa.edu 